\title{
FAKTOR-FAKTOR INTERNAL YANG MEMPENGARUHI MAHASISWA PENDIDIKAN TEKNOLOGI AGROINDUSTRI DALAM PEMILIHAN KARIR
}

\author{
Internal Factors Affecting Students of Agro-industry Technology Education Study Program \\ In Career Choice
}

\author{
Mega Kusumah Putri ${ }^{1}$, Yatti Sugiarti ${ }^{2}$, Mustika Nuramalia Handayani ${ }^{3}$ \\ 1,2,3 Program Studi Pendidikan Teknologi Agroindustri, \\ Fakultas Pendidikan Teknologi dan Kejuruan, Universitas Pendidikan Indonesia \\ E-mail: attisugiarti5@upi.edu
}

\begin{abstract}
ABSTRAK
Penelitian ini bertujuan untuk mengetahui 1) pengaruh faktor persepsi dalam pemilihan karir mahasiswa pendidikan teknologi agroindustri; 2) pengaruh faktor motivasi dalam pemilihan karir mahasiswa pendidikan teknologi agroindustri; 3) pengaruh faktor kemampuan akademik dalam pemilihan karir mahasiswa pendidikan teknologi agroindustri; 4) Faktor manakah yang paling berpengaruh dalam pemilihan karir mahasiswa pendidikan teknologi agroindustri. Penelitian ini termasuk penelitian deskriptif dengan pendekatan kuantitatif yang meneliti pengaruh hubungan variabel bebas dan variabel terikat. Populasi penelitian adalah mahasiswa Program Studi Pendidikan Teknologi Agroindustri. Sampel penelitian berjumlah 74 mahasiswa Prodi Pendidikan Pendidikan Teknologi Agroindustri angkatan 2012 dan 2013. Pengumpulan data dilakukan dengan kuesioner dan dokumentasi nilai IPK mahasiswa, analisis data mengunakan analisis regresi sederhana dan regresi berganda. Hasil penelitian menunjukkan bahwa 1) faktor persepsi berpengaruh dengan kontribusi $6,00 \%$ dalam pemilihan karir mahasiswa pendidikan teknologi agroindustri; 2) faktor motivasi berpengaruh dengan kontribusi $6,04 \%$ dalam pemilihan karir mahasiswa pendidikan teknologi agroindustri; 3) faktor kemampuan akademik berpengaruh dengan kontribusi $1,85 \%$ dalam pemilihan karir mahasiswa pendidikan teknologi agroindustri; 4) faktor motivasi paling berpengaruh dibandingkan dengan faktor persepsi dan faktor kemampuan akademik dalam pemilihan karir mahasiswa pendidikan teknologi agroindustri.

Kata Kunci: faktor internal, pemilihan karir
\end{abstract}

\begin{abstract}
This study aims to determine 1) the influence of perceptions in career choice of agro-industrial technology education students; 2) the influence of motivational factors in career choice of agrotechnology education students; 3) the influence of academic ability in career choice of agrotechnology education students; 4) Which factor is most influential in career choice of agro-industrial technology education student. This research was descriptive with quantitative approach which examines the influence of relations independent and dependent variables. The study population is students of Agro-Industry Technology Education Study Program. These samples included 74 students of class 2012 and 2013. The data was collected by questionnaire and documentation of student GPA, data analysis using simple regression analysis and regression. The results showed that 1) the perception factors influence career choice of agro-industrial technology education students with contribution of $6.00 \%$; 2) the motivational factors influence career choice of agroindustrial technology education students with contribution of $6.04 \%$; 3) the academic abilities factors influence career choice of agro-technology career education students with $1.85 \%$ contribution; 4) The motivating factor is the most influential factor among the factor of perception and academic abilities factor in career choice of agro-industrial technology education students.
\end{abstract}

Keyword : internal factors, career choice 


\section{PENDAHULUAN}

Program studi Pendidikan Teknologi Agroindustri merupakan salah satu program studi di Fakultas Pendidikan Teknologi dan Kejuruan - Universitas Pendidikan Indonesia. Adapun visi dari program studi Pendidikan Teknologi Agroindustri yaitu menjadi program studi pelopor dan unggul dalam bidang Ilmu Pendidikan Teknologi Agroindustri. Serta misi dari program studi Pendidikan Teknologi Agroindustri yaitu untuk menyelenggarakan program Pendidikan Teknologi Agroindustri untuk mempersiapkan tenaga pendidik profesional yang mampu bersaing di tingkat nasional.

Menurut Ardyani (2014), pemilihan karir erat kaitannya dengan minat yang dimiliki guna menunjang proses karir yang ditempuhnya. Minat tidak terbentuk begitu saja dalam diri seseorang, melainkan muncul dari pengaruh faktor intern dan faktor ekstern, faktor intern merupakan faktor yang mampu menumbuhkan minat seseorang karena adanya kesadaran dari diri sendiri tanpa ada paksaan dari orang lain seperti faktor emosional, persepsi, motivasi, bakat dan penguasaan ilmu pengetahuan sedangkan faktor ekstern yaitu faktor yang mampu menumbuhkan minat seseorang akibat adanya peran orang lain dan lingkungan yang ada di sekitar seperti faktor lingkungan keluarga dan lingkungan sosial. Demikian pula dengan pemilihan karir dari mahasiswa pendidikan teknologi agroindustri di bidang pendidikan maupun non-pendidikan memerlukan penggalian minat yang dapat dibentuk oleh mahasiswa dengan mengacu pada faktor intern dan ekstern.

Salah satu faktor yang cukup berpengaruh dapat kita lihat melalui faktor internal yaitu bagaimana mahasiswa melakukan pemilihan karir dengan kesadaran dirinya tanpa ada paksaan dari apapun. Harisanto (2006) dalam penelitiannya menemukan bahwa faktor internal lebih mempengaruhi keputusan memilih karir pada remaja dibanding faktor dari luar.

Dalam pemilihan karir terdapat beberapa faktor yang harus dipertimbangkan yaitu lingkungan keluarga, dan kemampuan akademik mahasiswa tersebut (Ferry, 2013). Namun peneliti disini akan menggunakan faktor-faktor internal yang di anggap dapat mempengaruhi minat pemilihan karir yaitu faktor persepsi, motivasi dan kemampuan akademik.

Berdasarkan visi, misi dan tujuan dari Program Studi Pendidikan Teknologi Agroindustri, dapat diketahui bahwa lulusan prodi PTAG akan lebih diarahkan bekerja di bidang pendidikan. Namun pada kenyataannya, berdasarkan studi pendahuluan yang telah dilakukan oleh peneliti kepada mahasiswa PTAG angkatan 2012 sebanyak 18 orang, didapatkan hasil yang menyatakan bahwa yang berminat untuk berkarir di bidang pendidikan sebanyak $39 \%$, sedangkan mahasiswa yang berminat untuk berkarir di bidang non-pendidikan sebanyak $44 \%$. Mahasiswa yang memilih kedua karir di bidang pendidikan dan bidang non-pendidikan sebanyak $17 \%$. Berdasarkan hasil studi pendahuluan tersebut menunjukkan bahwa terdapat banyak mahasiswa yang tidak ingin berkarir di bidang pendidikan khususnya menjadi guru.

Tujuan penelitian ini yaitu untuk mengetahui 1) pengaruh faktor persepsi dalam pemilihan karir mahasiswa pendidikan teknologi agroindustri; 2) pengaruh faktor motivasi dalam pemilihan karir mahasiswa pendidikan teknologi agroindustri; 3) pengaruh faktor kemampuan akademik dalam pemilihan karir mahasiswa pendidikan teknologi agroindustri; 4) Faktor manakah yang paling berpengaruh dalam pemilihan karir mahasiswa pendidikan teknologi agroindustri.

\section{METODE}

Penelitian ini termasuk penelitian deskriptif dengan pendekatan kuantitatif. Populasi dalam penelitian ini adalah seluruh mahasiswa Pendidikan Teknologi Agroindustri FPTK UPI. Sementara itu sampel yang digunakan yaitu mahasiswa Pendidikan Teknologi Agroindustri angkatan 2012 dan 2013 berjumlah 74 mahasiswa.

Variabel independent (bebas) dan variabel dependent (terikat) pada penelitian ini antara lain: Faktor Persepsi $\left(X_{1}\right)$, Faktor Motivasi $\left(X_{2}\right)$, dan Faktor Kemampuan Akademik $\left(X_{3}\right)$ sebagai variabel bebas, sedangkan Pemilihan Karir Mahasiswa Pendidikan Teknologi Agroindustri $(Y)$ sebagai variabel terikat.

Pengumpulan data yang digunakan pada penelitian ini menggunakan dokumentasi transkrip nilai mahasiswa dan kuesioner. Analisis data menggunakan bantuan program SPSS 22 for Windows. 
Teknik analisis data yang digunakan antara lain: (1) Deskriptif Data; (2) Uji Normalitas; (3) Uji Homogenitas; (4) Uji Linieritas; (5) Uji Multikolinieritas; (6) Analisis Regresi Sederhana; dan (7) Analisis Regresi Berganda.

\section{HASIL DAN PEMBAHASAN}

\section{Pemilihan Karir}

Pemilihan karir pada penelitian ini merupakan pemilihan jenis karir mahasiswa Pendidikan Teknologi Agroindustri di bidang pendidikan atau bidang non-pendidikan serta alasan dalam pemilihan karir tersebut. Pemilihan karir ini merupakan variabel dependen atau variabel yang dipengaruhi oleh variabel independen $(Y)$. Data variabel $Y$ diperoleh menggunakan teknik pengumpulan data berupa kuesioner yang diberikan kepada setiap sampel berupa butir-butir pernyataan dan skala pengukuran yang digunakan yaitu skala Guttman. Jumlah responden yang digunakan berjumlah 74 orang yaitu mahasiswa Pendidikan Teknologi Agroindustri angkatan 2012 dan 2013. Jumlah butir pernyataan pada kuesioner yang diberikan kepada responden untuk mengetahui pemilihan karir mahasiswa yaitu sebanyak 10 butir pernyataan dan pernyataan pemilihan mengenai jenis karir yang diminati oleh mahasiswa. Berikut merupakan diagram pemilihan karir yang diminati oleh mahasiswa Pendidikan Teknologi Agroindustri yang disajikan pada Gambar 1.

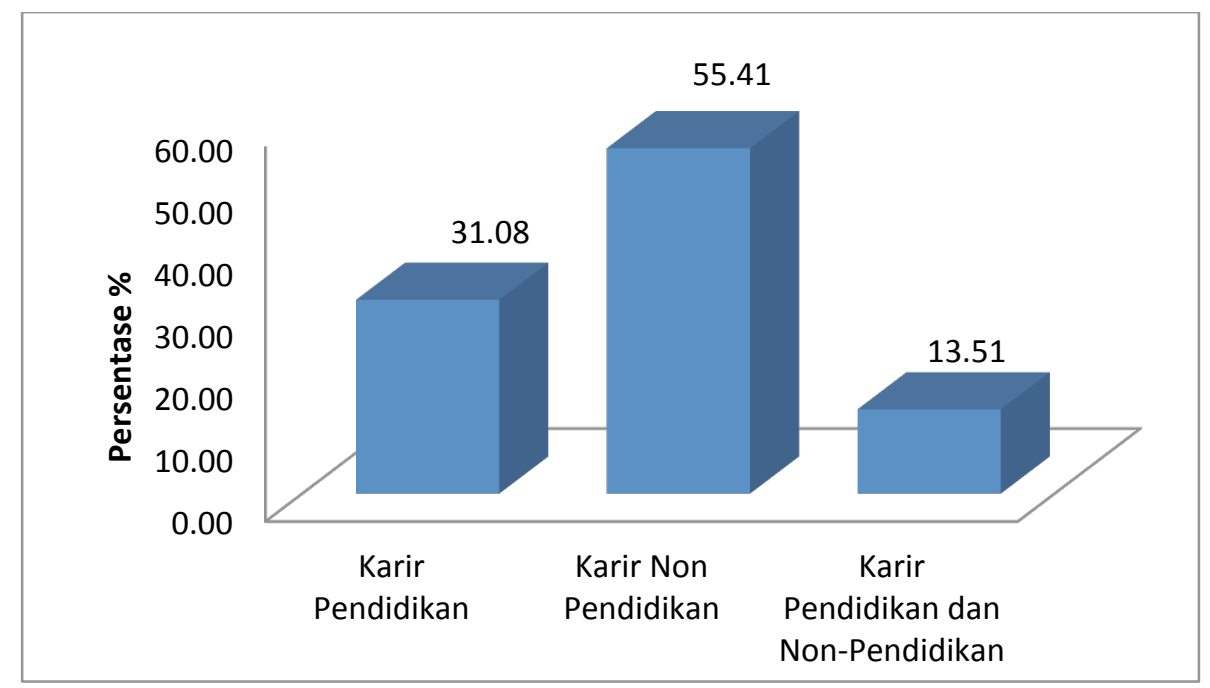

Gambar 1. Persentase Pilihan Minat Karir Mahasiswa Pendidikan Teknologi Agroindustri

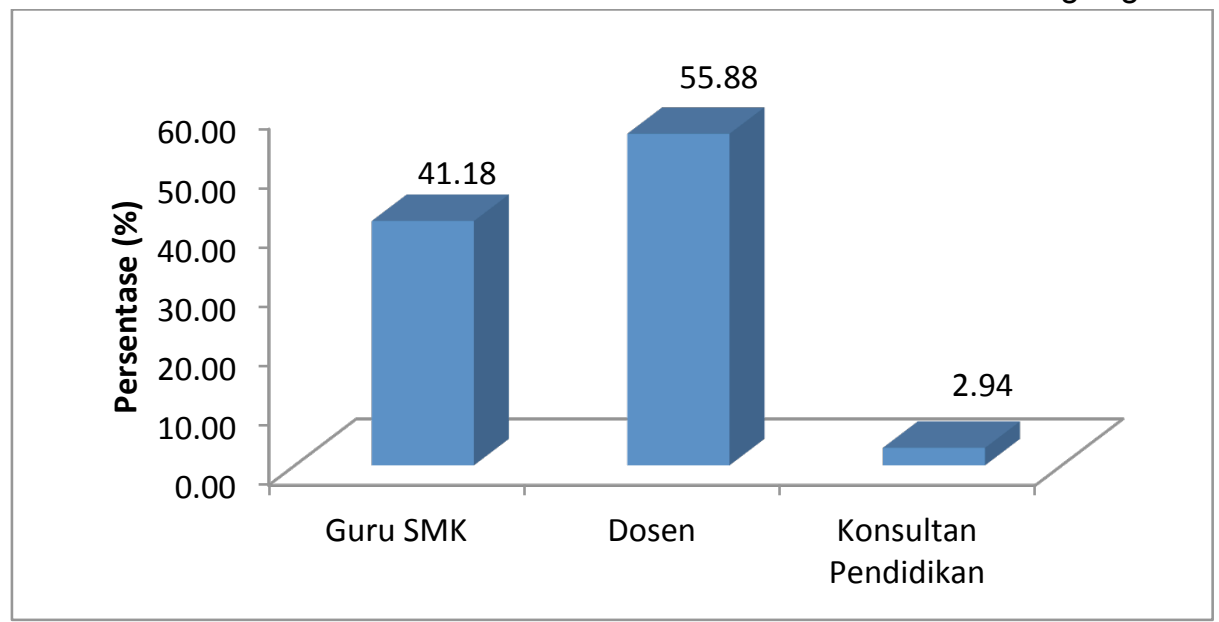

Gambar 2. Persentase Pilihan Karir di Bidang Pendidikan Mahasiswa Pendidikan Teknologi Agroindustri 


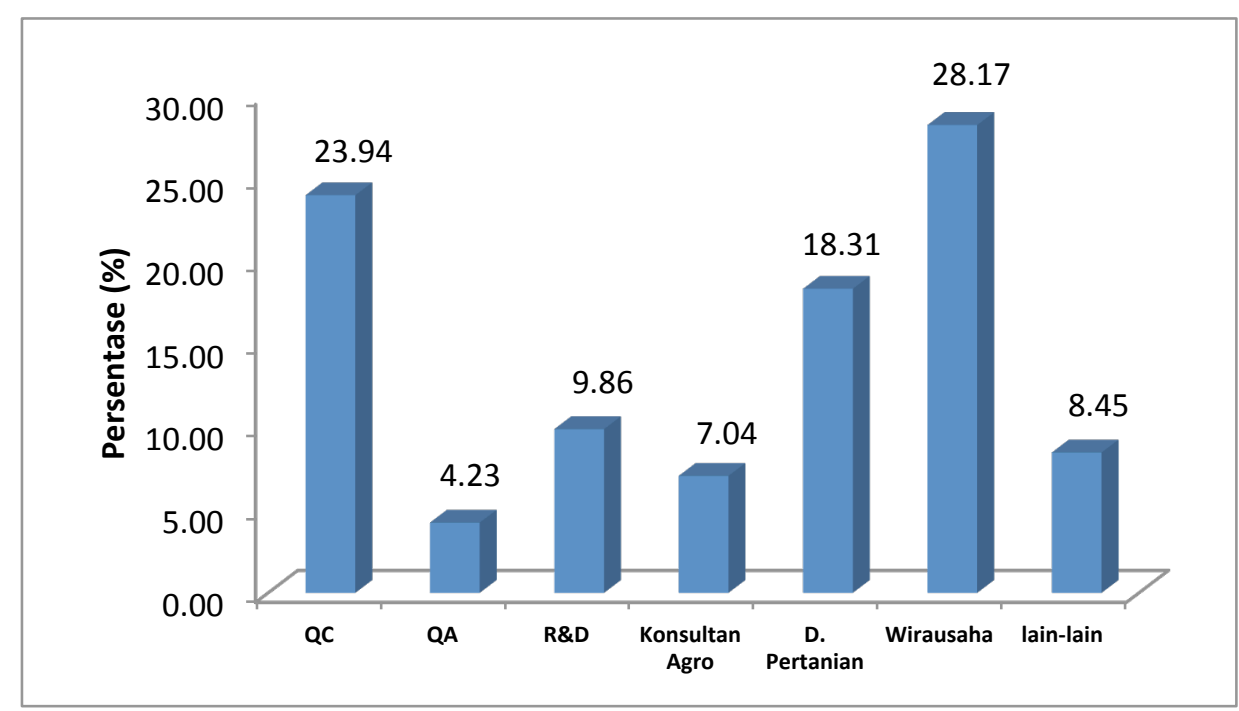

Gambar 3. Persentase Pilihan Karir di Bidang Non Pendidikan Mahasiswa Pendidikan Teknologi Agroindustri

\section{Faktor-Faktor Internal}

Faktor-faktor internal dalam pemilihan karir yang diteliti dalam penelitian ini, antara lain: persepsi, motivasi dan kemampuan akademik. Pengumpulan data pada penelitian ini menggunakan kuesioner pada variabel persepsi dan motivasi. Sedangkan untuk variabel kemampuan akademik menggunakan teknik studi dokumentasi, yaitu berupa nilai Indeks Prestasi Kumulatif (IPK) yang selanjutnya nilai IPK dari setiap sampel dirata-ratakan dan dipersentasekan. Sampel yang digunakan pada penelitian ini yaitu mahasiswa Pendidikan Teknologi Agroindustri angkatan 2012 dan 2013. Hasil studi dokumentasi maupun data kuesioner faktor-faktor internal terdapat pada Lampiran 10, 11, dan 12. Untuk lebih memperjelas sejauh mana faktor-faktor internal dalam pemilihan karir mahasiswa PTAG yaitu sebagai berikut

\section{a. Faktor Persepsi $\left(X_{1}\right)$}

Faktor persepsi $\left(\mathrm{X}_{1}\right)$ yang diteliti meliputi indikator pengalaman, kebutuhan dan perhatian.

1) Pengalaman

Hasil tanggapan responden tertinggi mengenai faktor persepsi pada indikator pengalaman yaitu $90,54 \%$ yang berarti sebanyak $90,54 \%$ responden memiliki persepsi bahwa kesempatan untuk mendapatkan karir yang diminati tidak mudah jika tidak memiliki keterampilan khusus. Pengalaman yang berkaitan dengan karir yang diminati dapat dijadikan sebagai alasan persepsi/pandangan responden dalam memilih karir seperti telah melakukan berbagai pelatihan yang berkaitan dengan karir yang diminati.

2) Kebutuhan

Hasil tanggapan responden tertinggi mengenai faktor persepsi pada indikator kebutuhan yaitu $89,86 \%$ yang berarti sebanyak $89,86 \%$ responden memiliki persepsi bahwa responden memilih karir yang masih memberikan kesempatan waktu luang sehingga dapat menyalurkan kebutuhan hobi dan aktualisasi diri. Kebutuhan baik dalam segi finansial pribadi, finansial keluarga, maupun kebutuhan dalam memiliki karir yang dapat menyalurkan hobi serta karir yang memiliki masa depan yang sukses.

\section{3) Perhatian}

Hasil tanggapan responden tertinggi mengenai faktor persepsi pada indikator perhatian yaitu $89,86 \%$ yang berarti sebanyak $89,86 \%$ responden memiliki persepsi bahwa responden memilih karir yang memiliki persaingan tinggi antar karyawan. Perhatian dalam memilih karir 
merupakan pandangan/persepsi awal mahasiswa dengan menilai karir berdasarkan kesenangan serta persaingan dalam karir yang dipilih.

\section{b. Faktor Motivasi $\left(\mathrm{X}_{2}\right)$}

Faktor motivasi $\left(\mathrm{X}_{2}\right)$ yang diteliti meliputi indikator cita-cita dan usaha pencapaian karir.

\section{1) Cita-cita karir}

Hasil tanggapan responden tertinggi mengenai faktor motivasi pada indikator cita-cita karir yaitu $83,11 \%$ yang berarti sebanyak $83,11 \%$ responden memiliki motivasi bahwa responden memiliki keinginan besar untuk meraih cita-cita karir. Cita-cita mahasiswa dalam memilih karir dapat disebabkan oleh keinginan diri sendiri, keinginan memilih karir yang sesuai dengan pengalaman, kesesuaian dengan latar belakang pendidikan yang dimiliki responden, serta sikap optimis yang dimiliki responden.

\section{2) Usaha Pencapaian Karir}

Hasil tanggapan responden tertinggi mengenai faktor motivasi pada indikator usaha pencapaian karir yaitu $83,78 \%$ yang berarti sebanyak $83,78 \%$ responden memiliki motivasi bahwa responden belajar dengan giat agar tercapai karir yang diinginkan. Usaha pencapaian karir yang diinginkan responden yaitu dengan melakukan usaha semaksimal mungkin dengan belajar serta meningkatkan pengetahuan maupun keahlian yang disesuaikan dengan karir yang akan dipilih.

\section{c. Faktor Kemampuan Akademik $\left(\mathrm{X}_{3}\right)$}

Faktor kemampuan akademik diperoleh dari studi dokumentasi nilai Indeks Prestasi Kumulatif (IPK) mahasiswa yang dapat dijadikan sebagai faktor kemampuan akademik $\left(\mathrm{X}_{3}\right)$ dalam pemilihan karir mahasiswa Pendidikan Teknologi Agroindustri. Berikut merupakan diagram hasil nilai IPK mahasiswa Pendidikan Teknologi Agroindustri sebagai variabel $\mathrm{X}_{3}$ (faktor kemampuan akademik) dapat dilihat pada Gambar 4.

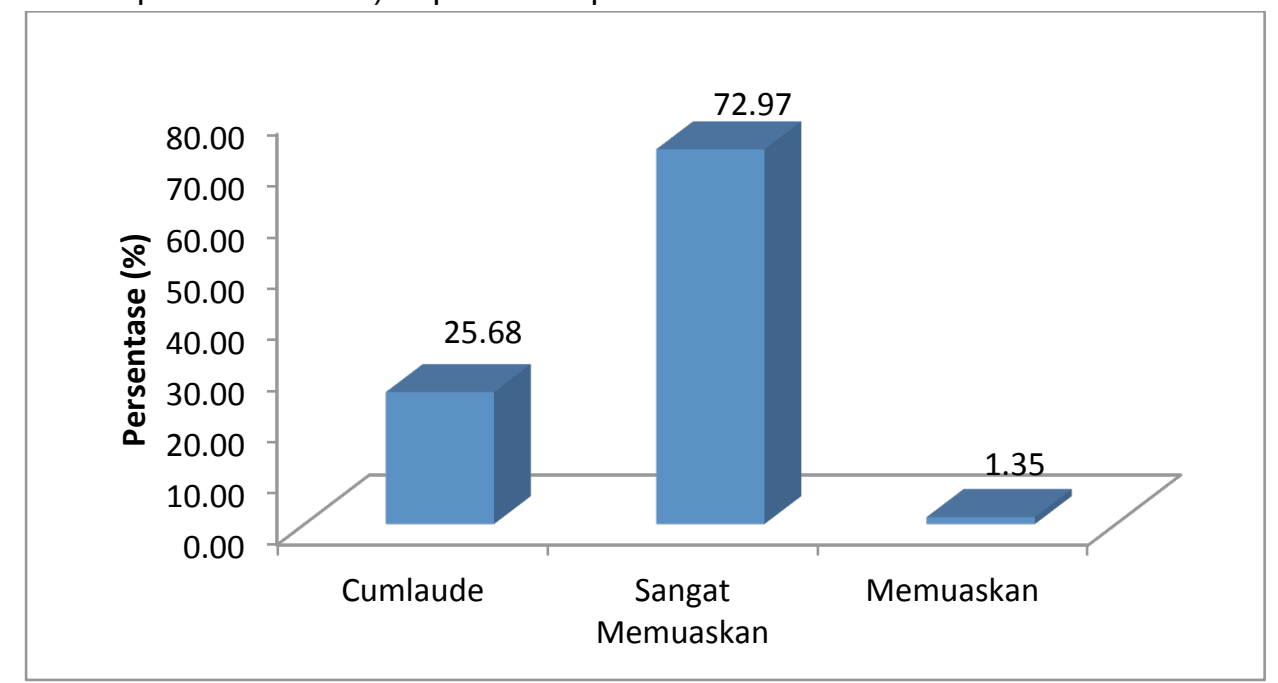

Gambar 4. Persentase Kemampuan Akademik (Nilai IPK) Mahasiswa Pendidikan Teknologi Agroindustri.

\section{Pengujian Hipotesis}

Pengujian hipotesis dilakukan untuk mengetahui ada tidaknya pengaruh antara variabel bebas dengan variabel terikat. Pengujian hipotesis menggunakan uji t student dan uji $f$ dengan taraf signifikansi $5 \%$. Nilai yang diperoleh dari perhitungan statistik dibandingkan dengan nilai dalam tabel 1. 
Tabel.1 Ringkasan Hasil Nilai pada Uji Hipotesis

\begin{tabular}{|c|c|c|c|c|c|}
\hline Variabel & $\mathbf{D k}$ & $\mathbf{t}_{\text {hitung }}$ & $\mathbf{t}_{\text {tabel }}$ & $\mathbf{A}$ & $\mathbf{S i g}$. \\
\hline $\mathrm{X}_{1}$ terhadap $\mathrm{Y}$ & 70 & 3,097 & 1,667 & 0,05 & 0,003 \\
\hline $\mathrm{X}_{2}$ terhadap $\mathrm{Y}$ & 70 & 6,361 & 1,667 & 0,05 & 0,000 \\
\hline $\mathrm{X}_{3}$ terhadap $\mathrm{Y}$ & 70 & 3,586 & 1,667 & 0,05 & 0,001 \\
\hline Variabel & $\mathbf{D k}$ & $\mathbf{F}_{\text {hitung }}$ & $\mathbf{F}_{\text {tabel }}$ & $\mathbf{A}$ & $\mathbf{S i g}$. \\
\hline $\mathrm{X}_{1}, \mathrm{X}_{2}, \mathrm{X}_{3}$ terhadap $\mathrm{Y}$ & 70 & 3,757 & 2,735 & 0,05 & 0,015 \\
\hline
\end{tabular}

\section{a. Uji Hipotesis Pertama}

Hipotesis pertama dalam penelitian ini adalah faktor persepsi berpengaruh signifikan dalam pemilihan karir mahasiswa Pendidikan Teknologi Agroindustri. Hasil $t_{\text {hitung }}$ pada penelitian ini yaitu sebesar 3,097 sedangkan $t_{\text {tabel }}$ pada taraf signifikansi 0,05 sebesar 1,667 sehingga dapat disimpulkan bahwa koefisien konstanta pada penelitian ini yaitu $\mathrm{H}_{\circ}$ ditolak dan $\mathrm{H}_{1}$ diterima karena $\mathrm{t}_{\text {hitung }}$ lebih besar dari $\mathrm{t}_{\text {tabel }}(3,097>1,667)$. Berdasarkan tingkat signifikansi dan koefisien konstanta maka dapat ditarik kesimpulan bahwa "Faktor persepsi berpengaruh signifikan dalam pemilihan karir mahasiswa Pendidikan Teknologi Agroindustri".

\section{b. Uji Hipotesis Kedua}

Hipotesis kedua dalam penelitian ini adalah faktor motivasi berpengaruh signifikan dalam pemilihan karir mahasiswa Pendidikan Teknologi Agroindustri. Hasil thitung pada penelitian ini yaitu sebesar 6,361 sedangkan $t_{\text {tabel }}$ pada taraf signifikansi 0,05 sebesar 1,667 sehingga dapat disimpulkan bahwa koefisien konstanta pada penelitian ini yaitu $\mathrm{H}_{\circ}$ ditolak dan $\mathrm{H}_{2}$ diterima karena $t_{\text {hitung }}$ lebih besar dari $t_{\text {tabel }}(6,361>1,667)$. Berdasarkan tingkat signifikansi dan koefisien konstanta maka dapat ditarik kesimpulan bahwa "Faktor motivasi berpengaruh signifikan dalam pemilihan karir mahasiswa Pendidikan Teknologi Agroindustri".

\section{c. Uji Hipotesis Ketiga}

Hipotesis ketiga dalam penelitian ini adalah faktor kemampuan akademik berpengaruh signifikan dalam pemilihan karir mahasiswa Pendidikan Teknologi Agroindustri. Hasil $t_{\text {hitung }}$ pada penelitian ini yaitu sebesar 3,586 sedangkan $t_{\text {tabel }}$ pada taraf signifikansi 0,05 sebesar 1,667 sehingga dapat disimpulkan bahwa koefisien konstanta pada penelitian ini yaitu $H_{\circ}$ ditolak dan $H_{3}$ diterima karena $t_{\text {hitung }}$ lebih besar dari $t_{\text {tabel }}(3,586>1,667)$. Berdasarkan tingkat signifikansi dan koefisien konstanta maka dapat ditarik kesimpulan bahwa "Faktor kemampuan akademik berpengaruh signifikan dalam pemilihan karir mahasiswa Pendidikan Teknologi Agroindustri".

\section{d. Uji Hipotesis Keempat}

Hipotesis keempat dalam penelitian ini adalah faktor motivasi berpengaruh signifikan daripada faktor persepsi dan kemampuan akademik dalam pemilihan karir mahasiswa Pendidikan Teknologi Agroindustri. hasil uji $F$ diperoleh nilai $F_{\text {hitung }}$ sebesar 3,757. jika dibandingkan dengan nilai $F_{\text {tabel }}$ sebesar pada taraf signifikansi 0,05 , maka nilai $F_{\text {hitung }}>$ $F_{\text {tabel }}$ sehingga dapat dinyatakan bahwa "Faktor persepsi $\left(X_{1}\right)$, motivasi $\left(X_{2}\right)$ dan kemampuan akademik $\left(X_{3}\right)$ secara bersama-sama berpengaruh signifikan terhadap pemilihan karir mahasiswa Pendidikan Teknologi Agroindustri (Y)".

Hasil analisis regresi ganda tiga prediktor dapat diketahui besarnya Sumbangan relatif (SR) dan Sumbangan Efektif (SE) masing-masing variabel bebas (faktor persepsi, 
motivasi dan kemampuan akademik) terhadap pemilihan karir mahasiswa Pendidikan Teknologi Agroindustri. Besarnya SR dan SE dapat dilihat pada tabel 4.2.

Tabel 2. Nilai Sumbangan Efektif dan Sumbangan Relatif Variabel

\begin{tabular}{|c|c|c|c|c|c|c|}
\hline Variabel & B & $\begin{array}{l}\text { Cross } \\
\text { Product }\end{array}$ & Regresi & $\begin{array}{c}\text { SE Total } \\
(\%)\end{array}$ & $\begin{array}{l}\text { SE } \\
(\%)\end{array}$ & $\begin{array}{l}\text { SR } \\
(\%)\end{array}$ \\
\hline$X 1-Y$ & 0,228 & 102,784 & \multirow{3}{*}{54,252} & \multirow{3}{*}{13,9} & 6,00 & 43,20 \\
\hline$X 2-Y$ & 0,222 & 106,149 & & & 6,04 & 43,44 \\
\hline$X 3-Y$ & 0,873 & 8,286 & & & 1,85 & 13,33 \\
\hline \multicolumn{5}{|c|}{ JUMLAH } & 13,9 & 100 \\
\hline
\end{tabular}

Berdasarkan hasil perhitungan SR dan SE pada tabel 4.2 dapat diketahui bahwa faktor persepsi $\left(X_{1}\right)$ memberikan sumbangan relatif sebesar $43,20 \%$, faktor motivasi $\left(X_{2}\right)$ memberikan sumbangan relatif sebesar $43,44 \%$, dan faktor kemampuan akademik $\left(X_{3}\right)$ memberikan sumbangan relatif sebesar $13,33 \%$. Sedangkan sumbangan efektif masingmasing variabel adalah faktor persepsi $\left(X_{1}\right)$ memberikan sumbangan efektif sebesar $6,00 \%$, faktor motivasi $\left(X_{2}\right)$ memberikan sumbangan efektif sebesar $6,04 \%$, dan faktor kemampuan akademik $\left(X_{3}\right)$ memberikan sumbangan efektif sebesar $1,85 \%$. Sumbangan efektif total sebesar $13,9 \%$ yang berarti secara bersama-sama faktor persepsi, motivasi dan kemampuan akademik memberikan sumbangan efektif sebesar $13,9 \%$ terhadap pemilihan karir mahasiswa Pendidikan Teknologi Agroindustri, sedangkan sebesar $86,1 \%$ diberikan oleh variabel-variabel lain yang tidak dibahas dalam penelitian ini.

Maka, dapat disimpulkan bahwa pada penelitian ini $\mathrm{H}_{0}$ ditolak dan $\mathrm{H}_{4}$ diterima karena faktor motivasi memberikan sumbangan efektif dan relatif yang paling besar dibandingkan dengan faktor internal lainnya yaitu faktor persepsi dan faktor kemampuan akademik. Sehingga, dapat disimpulkan bahwa "Faktor motivasi $\left(\mathrm{X}_{2}\right)$ berpengaruh signifikan dibandingkan faktor persepsi $\left(X_{1}\right)$ dan kemampuan akademik $\left(X_{3}\right)$ dalam pemilihan karir mahasiswa Pendidikan Teknologi Agroindustri (Y)".

\section{Pengaruh Faktor Persepsi dalam Pemilihan Karir Mahasiswa Pendidikan Teknologi Agroindustri}

Pengaruh faktor persepsi sebagai variabel $X_{1}$ terhadap pemilihan karir mahasiswa Pendidikan Teknologi Agroindustri sebagai variabel $Y$ dapat dilihat pada persamaan $\hat{Y}=$ $\mathbf{9 , 3 6 6}+\mathbf{0 , 2 6 5} \mathbf{X}_{\mathbf{1}}$. Berdasarkan persamaan tersebut, nilai konstanta adalah 9,366 dan koefisien regresi adalah 0,265 , apabila ditarik garis linier maka dapat membentuk persamaan garis lurus yang mengartikan terdapat hubungan yang linier antara variabel. Artinya dalam persamaan regresi ini menunjukkan bahwa variabel faktor persepsi $\left(X_{1}\right)$ memiliki pengaruh positif terhadap variabel pemilihan karir mahasiswa Pendidikan Teknologi Agroindustri $(\mathrm{Y})$.

Persepsi setiap individu akan berbeda satu sama lain dan akan berpengaruh pada individu dalam memberikan pandangan terhadap karir yang akan dipilih, meskipun karir yang dipilih oleh setiap individu benar-benar sama atau berbeda. Dalam memilih karir yang akan dijalani, mahasiswa memiliki berbagai pertimbangan. Salah satu pertimbangan mahasiswa dalam memilih karir yang akan dijalaninya antara lain persepsi mengenai gaji yang didapatkan, persaingan antar karyawan, lingkungan kerja, pengalaman dan pengetahuan mengenai karir yang diminati. Perbedaan persepsi juga dapat disebabkan oleh adanya proses pembelajaran di perguruan tinggi menerima informasi yang berhubungan dengan profesi yang diminati. Informasi tersebut dapat memberikan persepsi yang berbeda pada masing-masing mahasiswa sesuai dengan karakteristik kepribadiannya dan pengetahuan intelektualnya. 


\section{Pengaruh Faktor Motivasi dalam Pemilihan Karir Mahasiswa Pendidikan Teknologi Agroindustri}

Pengaruh faktor motivasi sebagai variabel $X_{2}$ terhadap pemilihan karir mahasiswa Pendidikan Teknologi Agroindustri sebagai variabel $Y$ dapat dilihat pada persamaan $\hat{Y}=$

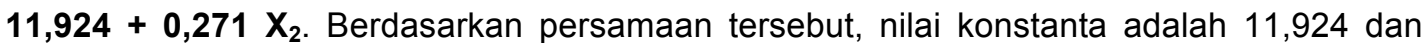
koefisien regresi adalah 0,271 apabila ditarik garis linier maka dapat membentuk persamaan garis lurus yang mengartikan terdapat hubungan yang linier antara variabel. Artinya dalam persamaan regresi ini menunjukkan bahwa variabel faktor motivasi $\left(X_{2}\right)$ memiliki pengaruh positif terhadap variabel pemilihan karir mahasiswa Pendidikan Teknologi Agroindustri (Y).

Faktor motivasi dapat mendorong atau mengarahkan mahasiswa untuk lebih berusaha untuk mencapai karir yang diminati dengan mempelajari atau mencari informasi mengenai karir baik dari teman yang sudah memiliki karir dan akan memiliki karir yang sama-sama diinginkan serta akan memunculkan motivasi dan keinginan yang cukup besar terhadap karir yang dipilih. Faktor motivasi lain yaitu dorongan dari keluarga yang akan selalu membimbing dan mengarahkan karir apa yang akan dipilih. Motivasi sangatlah penting karena motivasi adalah hal yang dapat menyebabkan, menyalurkan, dan mendukung perilaku mahasiswa dalam melakukan kegiatan atau rencana sehingga dapat mencapai karir dengan hasil yang baik.

\section{Pengaruh Faktor Kemampuan Akademik dalam Pemilihan Karir Mahasiswa Pendidikan Teknologi Agroindustri.}

Pengaruh faktor kemampuan akademik sebagai variabel $X_{3}$ terhadap pemilihan karir mahasiswa Pendidikan Teknologi Agroindustri sebagai variabel $Y$ dapat dilihat pada persamaan $\hat{Y}=11,465+1,502 X_{3}$. Berdasarkan persamaan tersebut, nilai konstanta adalah 11,465 dan koefisien regresi adalah 1,502, apabila ditarik garis linier maka dapat membentuk persamaan garis lurus yang mengartikan terdapat hubungan yang linier antara variabel. Artinya dalam persamaan regresi ini menunjukkan bahwa variabel faktor kemampuan akademik $\left(\mathrm{X}_{3}\right)$ memiliki pengaruh positif terhadap variabel pemilihan karir mahasiswa Pendidikan Teknologi Agroindustri $(Y)$.

Faktor kemampuan akademik terhadap pemilihan karir memiliki kontribusi yang sangat kecil dikarenakan mahasiswa yang akan memilih karir diminati menganggap IPK bukan halangan untuk bekerja karena IPK bukan ukuran yang pasti untuk mengukur kinerja seseorang. Akan tetapi faktor kemampuan akademik terhadap pemilihan karir juga dapat berpengaruh apabila karir yang akan dipilih membutuhkan keahlian atau kemampuan tertentu sehingga hal tersebut dapat menjadikan prestasi dalam karir.

\section{Pengaruh Faktor Persepsi, Motivasi, dan Kemampuan Akademik dalam Pemilihan Karir Mahasiswa Pendidikan Teknologi Agroindustri.}

Pengaruh faktor persepsi, motivasi dan kemampuan akademik sebagai variabel $X_{1}, X_{2}$ dan $X_{3}$ terhadap pemilihan karir mahasiswa Pendidikan Teknologi Agroindustri sebagai variabel $Y$ dapat dilihat pada persamaan $\hat{Y}=3,862+0,228 X_{1}+0,222 X_{2}+0,873 X_{3}$. Berdasarkan persamaan tersebut, nilai konstanta adalah 3,862 dan koefisien regresi adalah 0,228 pada variabel $X_{1}, 0,222$ pada variabel $X_{2}$, dan 0,873 pada variabel $X_{3}$, apabila ditarik garis linier maka dapat membentuk persamaan garis lurus yang mengartikan terdapat hubungan yang linier antara variabel. Persamaan tersebut dapat digunakan untuk memprediksi variabel dependen. Artinya dalam persamaan regresi ini menunjukkan bahwa nilai koefisien $X 1$ sebesar 0,228 yang berarti apabila nilai faktor persepsi $\left(X_{1}\right)$ meningkat 1 satuan maka nilai pemilihan karir mahasiswa PTAG akan meningkat sebesar 0,228 satuan 
dengan asumsi $X_{2}, X_{3}$ tetap. Koefisien $X_{2}$ sebesar 0,222 yang berarti apabila nilai faktor motivasi $\left(X_{2}\right)$ meningkat 1 satuan maka pertambahan nilai pemilihan karir akan meningkat 0,222 satuan dengan asumsi $X_{1}, X_{3}$ tetap. Koefisien $X_{3}$ sebesar 0,873 yang berarti apabila nilai faktor kemampuan akademik $\left(X_{3}\right)$ meningkat 1 satuan maka pertambahan nilai pemilihan karir akan meningkat 0,873 satuan dengan asumsi $X_{1}, X_{2}$ tetap.

Faktor motivasi memiliki pengaruh positif dibandingkan faktor persepsi dan kemampuan akademik terhadap pemilihan karir mahasiswa Pendidikan Teknologi Agroindustri. Faktor motivasi terdapat hubungan dengan persepsi. Hal tersebut sesuai dengan pendapat Danim (2004) bahwa motivasi diartikan sebagai kekuatan yang muncul dari dalam diri individu untuk mencapai tujuan atau keuntungan tertentu di lingkungan dunia kerja sehingga akan timbul persepsi yang berbeda-beda pada setiap mahasiswa terhadap penilaian suatu target yang akan dicapai. Berdasarkan respons positif, rasa senang terhadap suatu karir dapat timbul dan dipengaruhi beberapa faktor. faktor motivasi ini menegaskan bahwa motivasi akan mendorong mahasiswa untuk belajar dan berusaha agar menjadi apa yang diharapkan. Dorongan dari dalam diri mahasiswa ini harus selalu ditumbuhkan agar keberhasilan mahasiswa memilih karir yang diminati tercapai.

\section{KESIMPULAN}

1. Faktor persepsi berpengaruh dalam pemilihan karir mahasiswa Pendidikan Teknologi Agroindustri.

2. Faktor motivasi berpengaruh dalam pemilihan karir mahasiswa Pendidikan Teknologi Agroindustri.

3. Faktor kemampuan akademik berpengaruh dalam pemilihan karir mahasiswa Pendidikan Teknologi Agroindustri.

4. Faktor motivasi paling berpengaruh daripada faktor persepsi dan kemampuan akademik dalam pemilihan karir mahasiswa Pendidikan Teknologi Agroindustri.

\section{DAFTAR PUSTAKA}

Andriyani, Santi. (2013). Minat Kerja Mahasiswa Program Studi Pendidikan Teknologi Agroindustri FPTK UPI. Skripsi. UPI.

Aprylian, L. A. (2011). Faktor-Faktor Yang Mempengaruhi Mahasiswa Akuntansi Dalam Pemilihan Karir Menjadi Akuntan Publik. Skripsi. Universitas Diponegoro.

Ardyani, Anis. (2014). Analisis Faktor-Faktor yang Mempengaruhi Minat Mahasiswa Menjadi Guru Akuntansi Pada Mahasiswa Prodi Pendidikan Akuntansi Angkatan 2010 Universitas Negeri Semarang. Jurnal EEAJ volume 3 No. (2).

Danim, Sudarwan. (2004). Motivasi Kepemimpinan dan Efektivitas Kelompok. Jakarta: Rineka Cipta.

Ferry, Ifan. (2013). Studi Tentang Minat Mahasiswa Prodi Pendidikan Teknik Bangunan Angkatan 2009 UNNES Pada Dunia Kerja Antara Profesi Guru dan Profesi Dunia Teknik Sipil. Skripsi. Universitas Negeri Semarang.

Harisanto, R. (2006). Faktor-faktor Yang Mempengaruhi Keputusan Memilih Karir pada Remaja di SMA 2 Banjarmasin. Skripsi. Universitas Ahmad Dahlan Yogyakarta.

Rasmini, Ni Ketut. (2007). Faktor-faktor yang Berpengaruh Pada Keputusan Pemilihan Profesi Akuntan Publik dan Non Akuntan Publik Pada Mahasiswa Akuntansi di Bali. Skripsi. Universitas Udayana.

Walgito, Bimo. (1999). Pengantar Psikologi Umum. Yogyakarta: Andi Offset. 